\title{
Spatially explicit assessment of forest road suitability for timber extraction and hauling in Switzerland
}

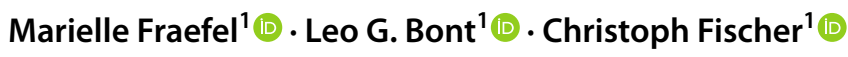

Received: 11 August 2020 / Revised: 23 April 2021 / Accepted: 8 June 2021 / Published online: 2 July 2021

(c) The Author(s) 2021

\begin{abstract}
Efficient forest management, and wood production in particular, requires a forest road network of appropriate density and bearing capacity. The road network affects the choice of a suitable extraction method and the length of the transport route from the forest, while the road standard defines the truck type that can be used.

We evaluate the forest road network's economic suitability for harvesting operations in the entire Swiss forest, an area of about 13,000 $\mathrm{km}^{2}$ covering a range of topographies, based on the Swiss National Forest Inventory's (NFI) forest road dataset. This dataset is based on information from an interview survey with the local forest services and includes all forest roads in Switzerland capable of carrying trucks. Extraction options and hauling routes are analysed together; thus, the entire logging process is examined.

Model results include maps of the most suitable extraction method; extraction costs; hauling costs; and a suitability map based on a combination of the results. While the larger part of the Swiss forest is classified as "suitable" for economic harvesting operations, significant portions also fall into the "limited suitability" and "not suitable" categories. Our analysis provides an objective, country-wide, spatially explicit assessment of timber accessibility. The resulting suitability map helps identify areas where timber harvesting is economic using the current forest road network, and where it is not. The model results can be used in road network planning and management, for example, by comparing road-network re-design scenarios, and compared to the spatial distribution of available wood volume.
\end{abstract}

Keywords Forest road network · Forest operations · Transport · Economic efficiency $\cdot$ Switzerland

\section{Introduction}

Efficient forest management and operations are a prerequisite for many ecosystem services (e.g. timber production, protective forest, recreation, biodiversity) as well as for making timber production profitable. To enable efficient management, it is essential that forests are well accessible by forest roads and state-of-the-art extraction technology can be used, as extraction and hauling account for a large share of the total costs of a forestry operation in most forestry settings (about 60\% in Switzerland (Bundesamt für Umwelt

Communicated by Eric R. Labelle.

Marielle Fraefel

marielle.fraefel@wsl.ch

$1 \quad$ Swiss Federal Institute for Forest, Snow and Landscape Research (WSL), Zuercherstrasse 111, 8903 Birmensdorf, $\mathrm{CH}$, Switzerland
BAFU 2017)). Many forestry enterprises are struggling to stay profitable and need to keep costs for off- and on-road wood transportation low.

A dense network of forest roads can reduce both extraction costs and hauling costs, by decreasing the extraction distances from the stand to the nearest road, and by shortening on-road hauling distances, respectively. In addition, roads with high bearing capacities can be used by heavy trucks and thus lead to a smaller number of trips necessary to transport a certain volume of wood, further reducing hauling costs. However, constructing and maintaining forest roads suitable for wood extraction and hauling is expensive. In the future, costs for the construction and maintenance of forest roads might rise due to the effects of climate change, because in many regions more intense precipitation events are expected (Croci-Maspoli et al. 2018) and might lead to higher erosion rates. At the same time, shorter soil freezing periods could limit ground trafficability and therefore ground-based wood extraction methods (Henry 2008). In addition, a road 
network that is too dense consumes a part of the forest area and can have negative ecologic effects such as increasing erosion (Spellerberg 1998). For these reasons, it is important to carefully evaluate the forest road network and allocate the (often scarce) resources available for the construction and maintenance of forest roads wisely.

An informed evaluation of the current situation requires detailed information about the existing road network and the resulting forest accessibility. The assessment of the economic efficiency of a forest road network should consider the cost contributions from extraction (off-road) and onroad transportation in combination. While expert opinion (and local knowledge) often plays an important role in the evaluation of forest road networks, it is desirable to have a method that is objective and reproducible and can be applied to large areas using the same criteria everywhere. Computer-aided approaches using such a method have been applied in the design of new forest road networks (Stückelberger et al. 2006), but without taking existing infrastructure into account. Before an existing forest road system can be improved, however, areas with insufficient access first have to be identified. The calculation of road density (or alternatively, road spacing), if calculated for a road network of irregular shape, gives a general estimate of the efficiency of the road network in a given area, but since road density is an average for this area, it does not allow to differentiate between easily accessible zones and zones with limited access. Hayati et al. (2012) demonstrate that high road density alone, and even high relative openness, does not necessarily result in overall short hauling distances, if there is large overlap of areas served by more than one road. Other evaluations focus on the extraction distance to the nearest road; this is a quick method yielding a spatially explicit result, but it looks at the extraction process in a simplified way, even if the straight-line distance to the nearest road is complemented with the vertical distance, ignoring soil properties and local steepness (Caliskan and Karahalil 2017; Laschi et al. 2016). Determining optimal extraction methods at sample plots allows to study the characteristics of each plot in detail, but the results cannot be transferred to the surrounding area if the terrain is variable and the road network irregular (Alberdi 2020). A number of studies have analysed either the extraction method (Caliskan and Karahalil 2017; Kuhmaier and Stampfer 2010; Suvinen 2006; Zambelli et al. 2012) or the hauling route (Akay and Kakol 2014), but not both at the same time. An approach to design a new road network that minimises on- and off-road transport (cable-yarding) at the same time was presented by Bont et al. (2015); however, this study did not evaluate an existing road network. Dupire et al. (2015) developed a method to determine forest accessibility based on three different extraction methods in a spatially explicit way for small areas, but did not consider on-road transportation. Havimo et al. (2017) present a model that takes into account road construction and timber transportation costs, as well as information on available stock, but consider only flat terrain and therefore do not differentiate between different extraction methods.

In areas with heterogeneous topography, comprising steep as well as level terrain, these approaches are not sufficient to evaluate wood accessibility because different extraction methods are applied depending on the local topography, ground trafficability and potential obstacles to ground-based extraction and cable-yarding, and because the forest road density is often highly variable due to the heterogeneous topography. Moreover, in many countries, forest roads serve a range of purposes in forest management, wildfire control and recreation and are not designed solely for wood extraction purposes; thus, their suitability for heavy wood transport vehicles varies.

Our study area is the country of Switzerland, situated in Central Europe, along the Alpine arc (Fig. 1). About 30\% of Switzerland are covered by forest (Abegg et al. 2014). Most forests in Switzerland are managed to fulfil multiple functions, with a combination of protective, recreational, ecological and economic uses. The dominant silvicultural regimes are based on selective cutting in even-aged or uneven-aged forests; clear cuts are prohibited by law. The predominant extraction methods are cable-based and ground-based (e.g. forest tractors), whereas helicopters are used occasionally.

The overall objective of our study is to provide fundamentals for decisions on the prioritisation of investments in road upgrade or construction, considering the topographical situation, for an existing forest road network. The following specific research questions are addressed: 1 . What is the distribution of different extraction methods (per area or per stock volume) for a particular region, and 2. where is the existing forest road network suitable for economic wood extraction, and where are do gaps lead to insufficient accessibility? Answering these questions requires a method which can spatially explicitly assess the suitability of the forest road network. In our study, we apply the approach described by Bont et al. (2018), as it corresponds best with our objective. It includes the modelling of extraction as well as hauling costs, and analyses the suitability of the terrain for ground-based and cable-based extraction methods. Using the resulting suitability map, any areas with inadequate forest accessibility can easily be identified. We adapt the method for use in a large and topographically diverse area; it has already been successfully tested in steep terrain. In addition, we compare our method to the analysis of sample plots in the Swiss National Forest Inventory (NFI). 

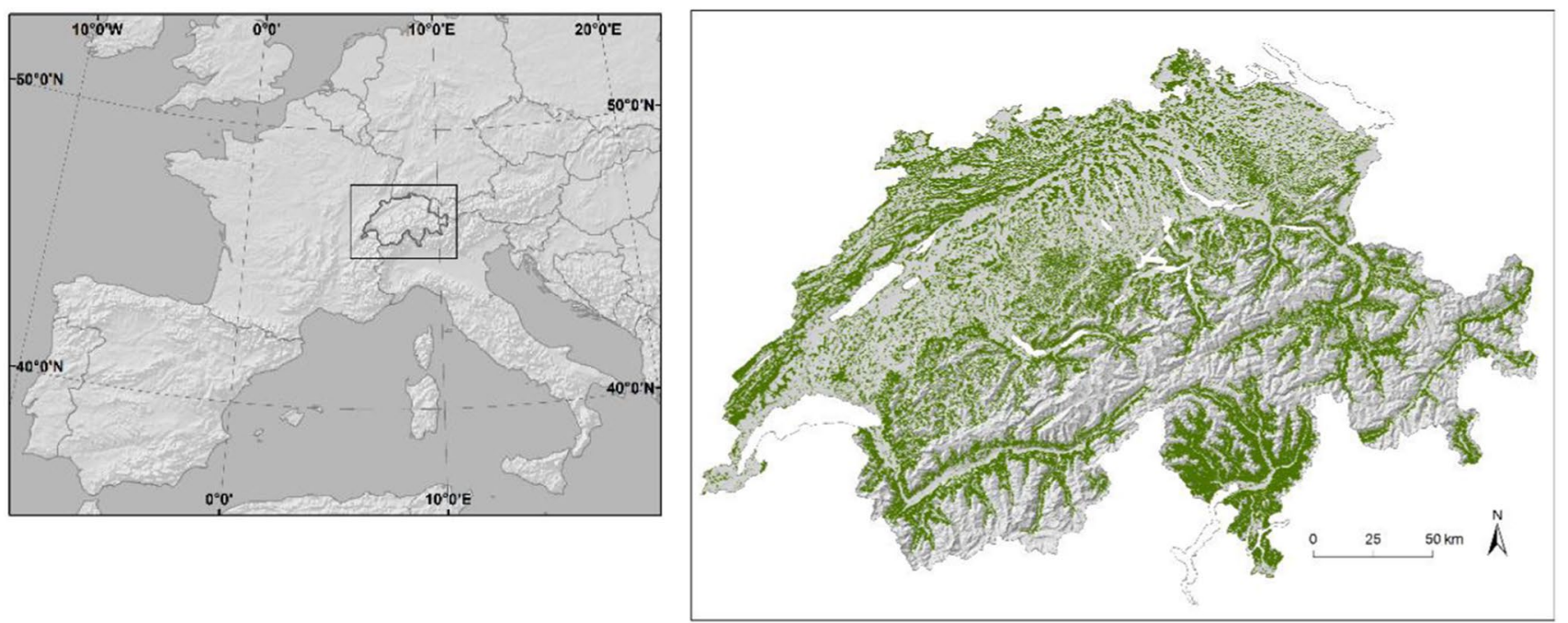

Fig. 1 Location of study area in Central Europe, topography and forest distribution. Sources: swisstopo / Swiss NFI. Reproduced by permission of swisstopo (JA100118)

\section{Materials and methods}

We use a reproducible, consistent way of assessing forest accessibility in a large area (ca. $40^{\prime} 000 \mathrm{~km}^{2}$ ) of heterogeneous terrain, taking both wood extraction and hauling into account and assuming the most cost-efficient combination is used. The criteria that are used are clearly defined and can be adapted to different study areas or different users' needs. Our analysis is based on information from the Swiss NFI, which provides data on the forest cover as well as the position and dimensions of all forest roads. Since collecting information on terrain morphology, obstacles and soil properties in the field is expensive, we use existing area-wide data for our analysis, based on, for instance, lidar data (digital terrain model (DTM), topographic landscape model (TLM)) and aerial images (TLM, forest cover map). This allows us to produce a spatially explicit result for the entire country. Our results are compared to plot-based information from the Swiss National Forest Inventory (NFI) and evaluated by two local forestry services. We analyse the existing road network, but the method also allows to compare different scenarios, e.g. the effect of newly built or upgraded roads.

\section{Accessibility analysis}

In our study, we analysed the costs of both extraction (offroad transportation) and hauling (on-road transportation), according to the method described by Bont et al. (2018). The methodology relies on studies that have optimised a cable road layout (Bont and Heinimann 2012; Bont et al. 2019; Heinimann 1986; Pestal 1961; Zweifel 1960) and studies that have analysed extraction and hauling together (Bont et al. 2015).
In a first step, potential landings were defined on a given forest road network at $30 \mathrm{~m}$ intervals. These were the transshipment points from off- to on-road transportation. Starting from these landings, radial lines of a length corresponding to the maximum yarding distance were drawn at $11.25^{\circ}$ intervals. $11.25^{\circ}$ intervals correspond to 32 radial lines. Theoretically, a line at $11.25^{\circ}$ or $22.5^{\circ}$ might not be feasible (e.g. because of obstacles), but an intermediate line at $16^{\circ}$ might be. However, since radial lines were tested again at a distance of $30 \mathrm{~m}$, it can be assumed that forest parcels that cannot be reached from one landing because of this gap between lines can usually be reached from a neighbouring landing. Along each straight radial line, the technical feasibility of cable roads was checked by finding the maximum feasible distance for a cable road with a maximum of five supports, using the approach of Pestal (1961) and a digital terrain model (DTM), an obstacle map and the forest cover map as input data (Fig. 2). Even unfavourable cable roads were tested on technical feasibility, e.g. perpendicular to the maximum slope, as in some cases no better alternative to access certain forest parcels could be found. Cable roads of two maximum lengths were differentiated, and up- and down-hill yarding directions were determined by comparing the altitude difference between the start and the end of the cable road. Forest parcels were regarded as accessible if they were within $30 \mathrm{~m}$ of a cable road. Next, areas where groundbased extraction is possible were identified, starting from all forest road pixels. Here, basically two extraction methods were considered: Skidder and Forwarder. We assumed that trafficable terrain is the same for both machines and consists of slopes of up to $35 \%$ on highly load-bearing ground, for example, soils with a high skeletal content (Eichrodt and Heinimann 2001), or slopes of up to $25 \%$ on soil susceptible 


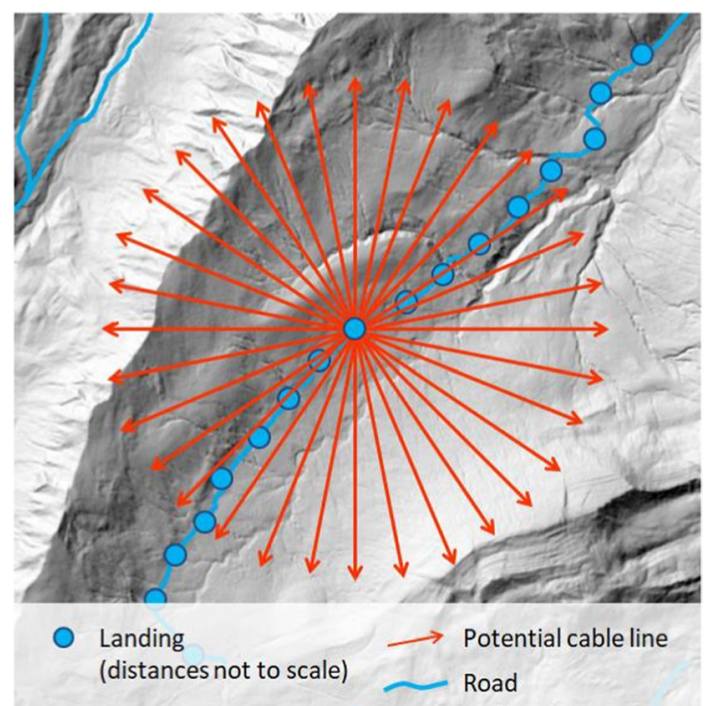

Fig. 2 Lines from potential landings along which the feasibility of cable roads is evaluated

to compaction, according to the Swiss soil suitability map (Swiss Federal Statistical Office (FSO) 2000). Further it was checked if those areas were within the maximum skidding distance from the landings and if they were connected to a road by trafficable area. For skidders, the accessible area can be extended by the use of a winch for pulling timber over $50 \mathrm{~m}$ in downhill direction, or $100 \mathrm{~m}$ in uphill direction. We did not take into consideration traction-assist winches on machinery, assuming they are used to make wood extraction safer and to avoid rutting, and not to work on steeper slopes. Of course, a given forest pixel may be reached from more than one landing, and using more than one extraction method. Next, harvesting costs were estimated for every forest parcel of $10 \times 10 \mathrm{~m}$, based on the extraction method and the hauling distance (Table 1). Where neither ground-based extraction nor cable-yarding was possible, extraction by helicopter was assumed and the area was designated as "unsuitable terrain". No cost was assigned to these pixels since helicopter-based extraction, although regularly applied in Switzerland, is usually not economic. A recent study in the Italian Alps mentions helicopter logging costs $\left(\right.$ per $\left.\mathrm{m}^{3}\right)$ that were four times the logging costs of a cable-crane system
(Manzone and Balsari 2017), in spite of much shorter operation times. Finally, the most economic extraction method was selected and assigned to each forest pixel.

In a second step, the potential routes from the landings out of the forest were analysed by network analysis. The endpoints of the transportation route-referred to as "connection points"-were defined as the points where the route reaches the superordinate road network, that is, a road that can be used by the largest truck type considered in the study at any time ( 5 axle trucks with $40 \mathrm{t}$ total weight), as determined in the interview survey of the Swiss NFI (Fischer and Fraefel 2019). Since the use of a larger truck reduces the number of trips necessary to transport a certain volume of wood (Table 2), and therefore hauling costs, we minimised the distance between a landing and the nearest connection point while maximising truck size. Travel time or speed was not explicitly considered. This seems justified since we only analyse the route through the forest and from the forest to the nearest higher-order road, so the larger part of the distance travelled consists of low-speed forest roads or small overland roads.

The method was originally developed for a study area with predominantly steep terrain (Bont et al. 2018) and was thoroughly tested and evaluated there. We applied it now to an entire country, comprising steep as well as hilly and flat topography. Some elements of the code were adapted; for instance, very steep $\left(>45^{\circ}\right)$ slopes were considered unsuitable for the operation of a cable-yarding system and were thus labelled as "unsuitable terrain". The analysis focuses on the economic efficiency of the extraction and hauling process; other factors, such as ecological aspects, are not included in the model.

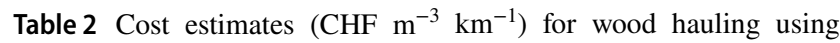
trucks of different sizes (from (Bont et al. 2018)

\begin{tabular}{lll}
\hline Truck category & Maximum weight [t] $\begin{array}{l}\text { Hauling } \\
\text { cost [CHF } \\
\left.\mathrm{m}^{-3} \mathrm{~km}^{-1}\right]\end{array}$ \\
\hline A & 20 & Not applicable \\
B (3-axle truck) & 26 & 0.91 \\
C (4-axle truck) & $28-32$ & 0.69 \\
D (5-/6-axle truck) & $40-44$ & 0.54 \\
\hline
\end{tabular}

Table 1 Extraction cost estimates $\left(\mathrm{CHF} \mathrm{m}^{-3}\right)$ for cableyarding and ground-based extraction used in the model (from Bont et al. 2018)

\begin{tabular}{lllllllll}
\hline Extraction method & \multicolumn{7}{l}{ Extraction distance (slope distance) [m] } \\
\cline { 3 - 8 } & & 0 & 250 & 500 & 750 & 1000 & 1250 & 1500 \\
\hline Tower yarder & Up-hill & 40 & 45 & 50 & 55 & 60 & - & - \\
& Down-hill & 50 & 55 & 60 & 65 & 70 & - & - \\
Long-distance yarder & Up-hill & 60 & 60 & 60 & 60 & 60 & 70 & 80 \\
& Down-hill & 70 & 70 & 70 & 70 & 70 & 80 & 90 \\
Ground-based (0-400 m) & & 40 & & & & & & \\
\hline
\end{tabular}


The calculations were done in MATLAB $®$ (The MathWorks Inc. 2016). To make dealing with large raster datasets possible and to keep calculations time within reasonable limits, the input raster datasets were tiled and the code adapted to allow parallel computations.

\section{Study area}

We carried out our study for the entire forest area in Switzerland (ca. 13,000 $\mathrm{km}^{2}$ ). Switzerland is a country of diverse landscape, from flat areas and rolling hills in the Plateau area to steeper hills and mountains of up to $1600 \mathrm{~m}$ in the Jura and Pre-Alps regions to mountainous topography in the Alps. About 30\% of Switzerland is covered by forest, reaching altitudes of about $2000 \mathrm{~m}$. At lower altitudes, beech and spruce forests dominate, while fir, spruce and lark dominate at higher altitudes. The forests in Switzerland are multifunctional, providing ecosystem services ranging from protection against natural hazards to timber production and recreation. The density of the existing forest road network is generally high, but spatially highly variable: on average, the country-wide density of roads capable of carrying 4-axle (32 $t$ ) trucks is $22 \mathrm{~m} \mathrm{ha}^{-1}$, ranging from $0 \mathrm{~m} \mathrm{ha}^{-1}$ to $84 \mathrm{~m} \mathrm{ha}^{-1}$ in individual forest management districts (Brändli et al. 2016). This depends mainly on the topography. In comparison, average forest road densities in other mountainous European countries range from $7.9 \mathrm{~m} \mathrm{ha}^{-1}$ in Bulgaria (Yonov and Velichkov 2004) to $45 \mathrm{~m} \mathrm{ha}^{-1}$ in Austria (Ghaffariyan et al. 2010). Forest road standards in Switzerland also vary widely (Fig. 3), with some areas relying on roads that only carry 2-axle trucks of less than 20 tons total weight and others where most roads are dimensioned for 5- or 6-axle trucks (40-ton total weight). Especially roads in steep areas often do not fulfil best-practice requirements and can only be used by small trucks. On the one hand, a large proportion of the roads were built in the 1960 and 1970s, when smaller trucks were used in forestry, and are now approaching the end of their expected lifespan. On the other hand, forest roads often serve other purposes besides wood extraction and hauling, such as access to agricultural land or recreational uses. To allow the use of heavier trucks and improve the competitiveness of the Swiss forestry sector-a goal declared by the federal government (Bundesamt für Umwelt BAFU 2013) lowering the expenses for timber extraction and hauling is a key factor. In order to identify gaps in the forest road network and to close them efficiently, an objective assessment of the existing forest road infrastructure is necessary.

The dominant wood extraction methods are ground-based (skidders, forwarders) in flat areas (about $80 \%$ of the forest area) and cable-based in steep areas (about 15\%), while helicopters are sometimes used in areas where neither ground-based nor cable-based extraction are possible, but forest management is still necessary (e.g. protective forest; about 5\%) (Brändli et al. 2020). In the Swiss NFI of 2009-2017, growing stock in the Swiss forest was estimated to be about $350 \mathrm{~m}^{3} \mathrm{ha}^{-1}$, considerably higher than in surrounding countries, where values ranged between about 150 $\mathrm{m}^{3} \mathrm{ha}^{-1}$ (France, Italy) and 300-320 $\mathrm{m}^{3} \mathrm{ha}^{-1}$ (Austria, Germany) (Brändli et al. 2020). In the nine years between NFI3 and NFI4, net growth was an average of $7.6 \mathrm{~m}^{3} \mathrm{ha}^{-1} \mathrm{a}^{-1}$ (or 9.1 million $\mathrm{m}^{3} \mathrm{a}^{-1}$ ) with large differences between different regions, ranging from $4.5 \mathrm{~m}^{3} \mathrm{ha}^{-1} \mathrm{a}^{-1}$ in the southern parts of the country to $12.0 \mathrm{~m}^{3} \mathrm{ha}^{-1} \mathrm{a}^{-1}$ in the Plateau region (Brändli et al. 2020). In this time period, $6.5 \mathrm{~m}^{3} \mathrm{ha}^{-1} \mathrm{a}^{-1}$ of
Fig. 3 Left: forest road for 26-ton trucks, right: forest road for 40-ton trucks according to NFI data, Plateau region, Switzerland
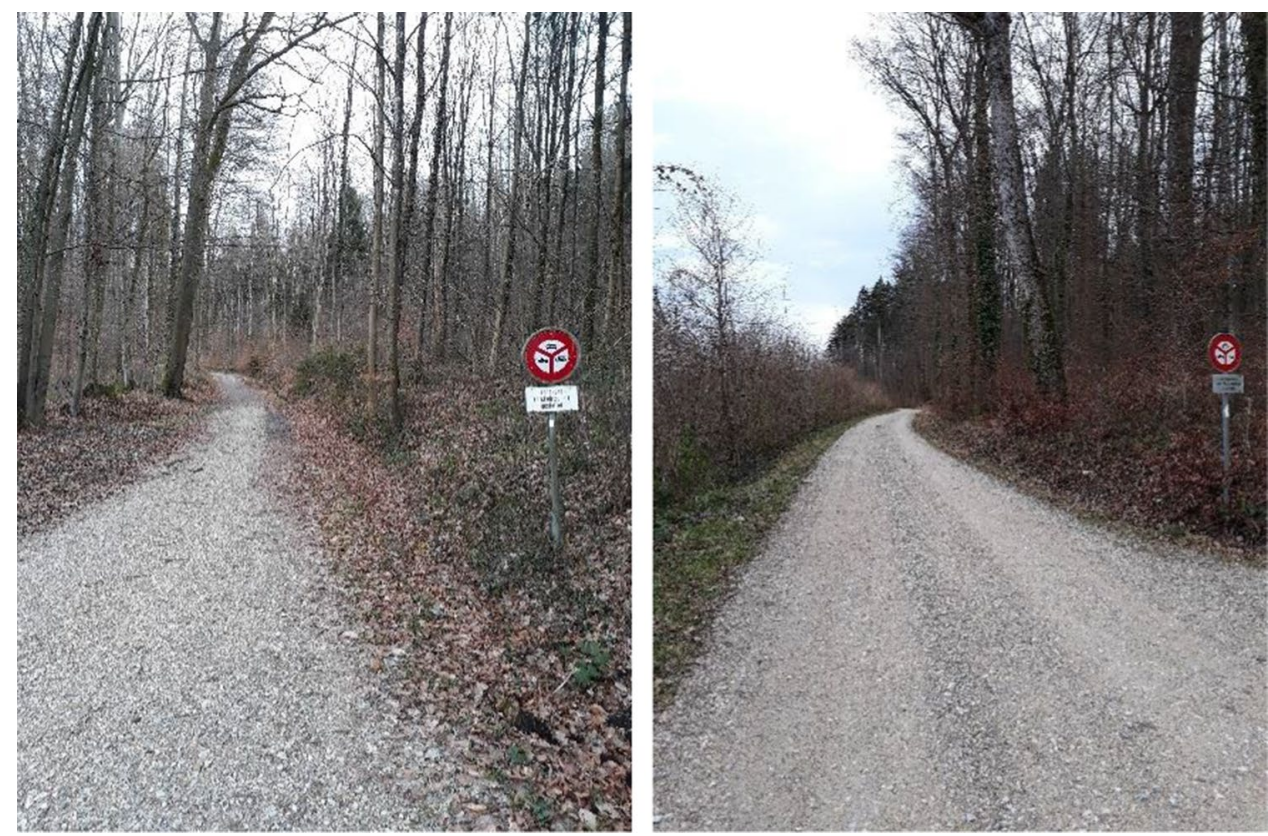
wood was used in all of Switzerland, i.e. about $85 \%$ of the net growth. Estimations for the annual potential wood supply from the Swiss forests range from 6 to about 8 million $\mathrm{m}^{3}$ (Hofer et al. 2011, Stadelmann et al. 2016). However, regionally only a fraction of the harvesting potential is actually harvested (Fischer and Camin 2015)-not surprisingly, considering low wood prices (an average of 70-90 CHF m ${ }^{-3}$ between 2015 and 2019 (Wald Schweiz)) and relatively high production costs (40-60 CHF m ${ }^{-3}$ between 1990 and 2014 on average (Murbach 2016), but over $100 \mathrm{CHF} \mathrm{m}^{-3}$ on a third of the forest area (Brändli et al. 2020)). $(1 \mathrm{CHF}=0.94$ EUR, or 1.04 USD).

Extraction and hauling cost estimations (Table 1, Table 2; Bont et al. (2018)) are based on the timber harvesting productivity model HeProMo (Erni 2003; Fischer and Stadelmann 2019; Frutig et al. 2009; Holm et al. 2020). The costs for ground-based extraction were assumed to be $40 \mathrm{CHF}$ $\mathrm{m}^{3}$ consistently. This is a comparatively high value which stands in relation to relatively high Swiss salaries; it may be lower in favourable cases and depending on the machinery that is used. However, whether a skidder or a forwarder is used depends on other factors, such as the wood sortiment, too, and is difficult to assess in our model. At the same time, costs of $40 \mathrm{CHF} \mathrm{m}^{3}$ are still lower than those for a cable yarder, so we do not expect this to introduce a systematic error in favour of cable yarding. With respect to common extraction procedures in Switzerland, maximum yarding distance was set to $1500 \mathrm{~m}$ and maximum skidding distance to $400 \mathrm{~m}$. For the model, transshipment points were set at intervals of $30 \mathrm{~m}$ along the forest roads.

\section{Input data}

The national swissTLM ${ }^{3 \mathrm{D}}$ road dataset provides accurate road geometries for the entire country, including forests. However, this dataset currently does not contain information on road width, bearing capacity and surface material relevant to the usability for forestry operations. This information has been collected by the NFI in an interview survey with foresters of all foresting districts in every inventory cycle since 1983 (Brassel and Lischke 2001; Fraefel and Fischer 2019; Müller et al. 2016). The resulting dataset consists of the swissTLM ${ }^{3 \mathrm{D}}$ geometries and additional attributes from the survey. It includes all forest roads that can be used for wood extraction and hauling and feature a minimum width of $2.5 \mathrm{~m}$ and a minimum bearing capacity of a 10-ton axle load. The dataset from the latest $\left(4^{\text {th }}\right)$ inventory also features information on road width and bearing capacity and the main roads connecting the larger forest roads to the road network that can be used by trucks of up to 40 tons all year round ('higher-order road network'). The interview survey also produced a "connection point" dataset of the locations where the forest roads or connection roads met the higher-order road network. For this study, all roads that can be used by a truck of 26 tons total weight or more, and are at least $3 \mathrm{~m}$ wide, were included in the road dataset $(83 \%$ of the total road length). This is based on the assumption that the installation of a tower yarder (TY) requires a road width of at least $3 \mathrm{~m}$ and trafficability for a 3-axle truck to access the landing.

Input data in raster format were: (1) the 2-m digital terrain model swissALTI ${ }^{3 \mathrm{D}}$ (swisstopo 2018) and, derived from it, a $2 \mathrm{~m}$ slope raster; the NFI's forest cover map (1 m resolution, Waser et al. (2015)); the Swiss soil suitability map (Swiss Federal Statistical Office (FSO) 2000) (originally in vector format); and a map of obstacles to the installation of cable roads created from elements (buildings, cables, railway lines and major roads) of the topographic landscape model swissTLM $^{3 \mathrm{D}}$ (swisstopo 2012). All raster data were resampled to a resolution of $10 \mathrm{~m}$. This resolution was chosen as a compromise between accurate representation of the real world on the one hand and too much noise from microtopography and exceedingly long computing times on the other hand. Vector datasets included the NFI forest road dataset with information indicating the type of truck that can be used on each road segment and a point dataset giving connection points where the roads from the forest connect to the superordinate road network (Fig. 4; Müller et al. (2016)).

\section{Results}

The distribution of extraction methods chosen by our model is spatially highly variable. Table 3 gives the resulting area for each extraction method in all of Switzerland as well as in five sub-regions of the country. We used the "production regions" defined in the Swiss NFI based on relatively homogeneous growth and wood production conditions (climate, topography, soil): Jura, Plateau, Pre-Alps, Alps and Southern Alps (Fig. 5; Fischer and Traub (2019)).

Ground-based extraction, up-hill yarding, down-hill yarding and unsuitable terrain (helicopter) were assigned to similar proportions of the total forest area in Switzerland (21-25\% each). The remaining $8 \%$ of the area were assigned long-distance up-hill yarding and long-distance down-hill yarding. The areas assigned to a certain extraction method were, however, not regularly distributed among the regions: for instance, ground-based extraction was assigned to 40 and $61 \%$ of the forest area in the Jura and Plateau, respectively, but only to 3-9\% of the forest area in the Pre-Alps, Alps and Southern Alps. In the Plateau, where flat areas and low slope gradients dominate, the dominant extraction method is ground-based, followed by unsuitable terrain, tower yarding and long-distance yarding. Jura and Pre-Alps have larger proportions of all cable-yarder classes than Plateau, but lower proportions of 


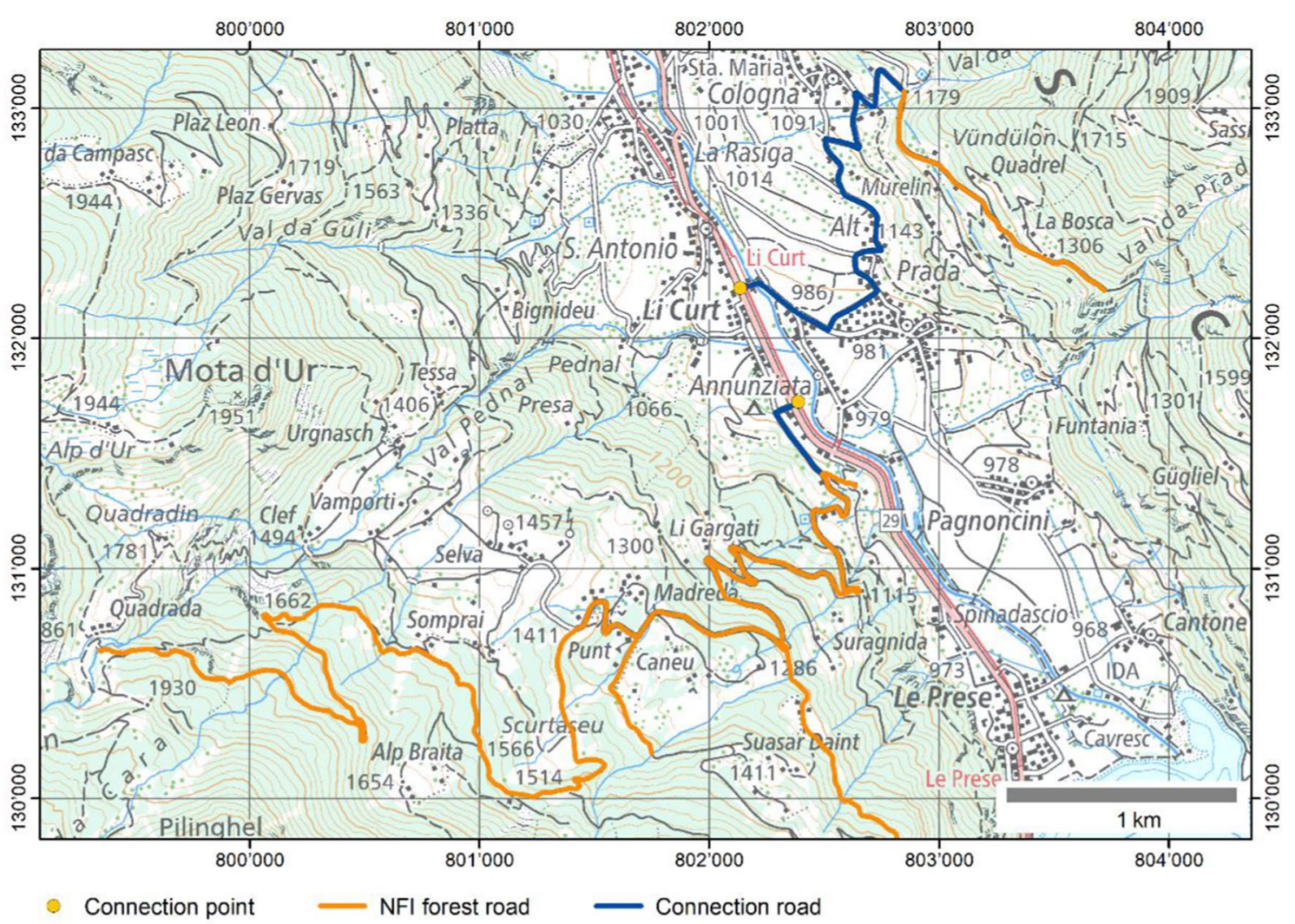

Fig. 4 Map extract from SE Switzerland with forest roads, connection roads and connection points of the Swiss NFI (2013/2014). Reproduced by permission of swisstopo (JA100118)

ground-based extraction. The largest difference in extraction methods assigned to the Jura and Pre-Alps regions can be found for the ground-based extraction method, the proportion of which is significantly larger in the Jura compared to the Pre-Alps. This might be due to the larger part of flat areas or the overall higher forest road density in the Jura. The Alps and Southern Alps regions are characterised by a very small part of the area to which ground-based extraction was assigned (4 and 3\%, respectively). The values for long-distance yarding are similar in the Alps and the Southern Alps (10 versus 11\%), but in the Alps, the proportion of tower yarding is much larger than in the Southern Alps (58 versus 26\%), while in the Southern Alps, the proportion of unsuitable terrain is much larger than in the Alps (61 versus 28\%). Long-distance yarding (up- and down-hill combined) plays a minor role in all regions, with the largest proportions occurring in the Alps (10\%) and Southern Alps (11\%).

We compared the resulting most suitable extraction method to the growing stock in the respective forest areas. We used the growing stock map compiled by Ginzler et al. (2019) for the entire Swiss forest and analysed it for all of Switzerland as well as for the five production regions, as presented in Table 4.
Here, too, the analysed regions show large differences. For example, in the Jura region, more than $80 \%$ of the growing stock is found in forests to which ground-based or cableyarding extraction methods were assigned. This is the case for only $39 \%$ of the growing stock in the Southern Alps. Generally, the percentages of growing stock closely resemble the percentages of area as presented in Table 3 .

Resulting extraction-cost estimations range from 40 to 80

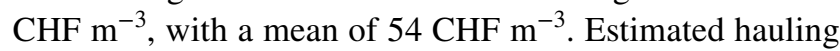
costs range from 0 to $19 \mathrm{CHF} \mathrm{m}^{-3}$, with a mean of $2 \mathrm{CHF}$ $\mathrm{m}^{-3}$. Figure 6 illustrates the resulting maps showing extraction method, extraction cost, hauling cost and total cost.

In order to assess the overall suitability of the Swiss forest for economic wood extraction and hauling, we applied the criteria defined in Table 6 to the entire forest area. This classification gives the highest rating ("suitable") to all forest areas which were assigned ground-based or tower-yarding extraction, in combination with hauling on roads that allowed the use of trucks of at least $28 \mathrm{t}$. The second-highest rating ("limited suitability") was given to forest areas which were assigned long-distance yarding, or a hauling route on smaller roads. All forest areas which were declared "unsuitable terrain" fell into the lowest class ("not suitable", Fig. 7). Using these criteria, $75 \%$ of the forest area falls into the 


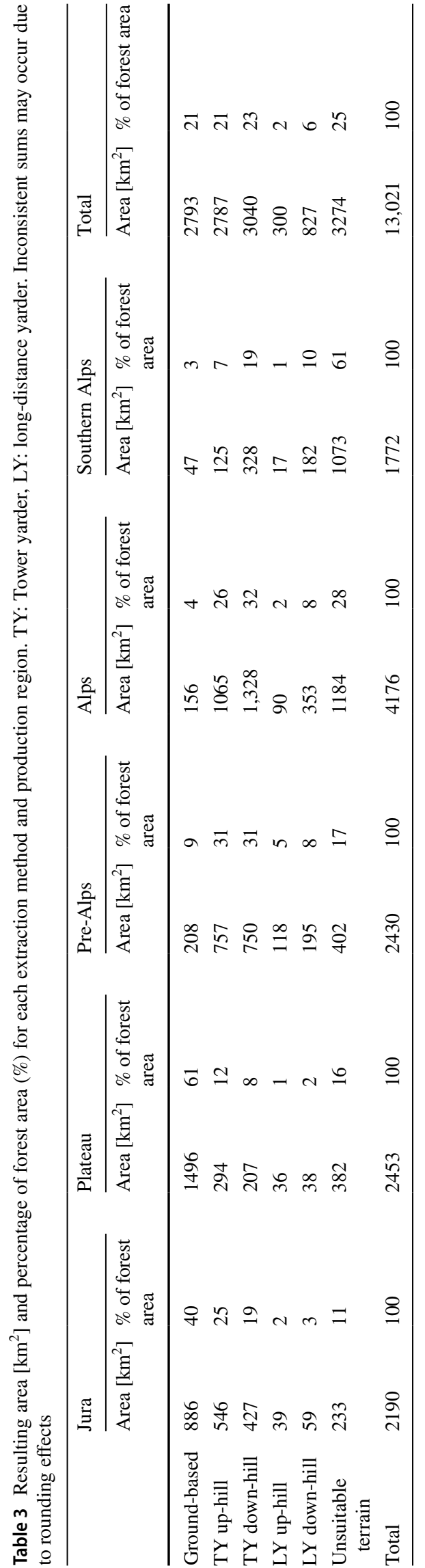

"suitable" and "limited suitability" classes (Table 5). The percentages of area falling into the lowest, "not suitable" category closely correspond to the values given in Table 3 for unsuitable terrain (25\%), indicating that the entire forest area in the "not suitable" category consists of forests with air-based extraction assigned. These classes are, of course, highly arbitrary and need to be adapted to the problem that is to be addressed.

\section{Discussion}

With our approach, we have achieved a consistent and spatially explicit evaluation of the forest accessibility in a large area of heterogeneous terrain, based on an existing forest road network. In contrast to other forest accessibility analyses, our method combines the evaluation of the most suitable extraction method and the best on-road transport route; it also integrates the roads' varying bearing capacities into the estimation of hauling costs.

The results show that wood accessibility is roughly correlated with topographic steepness, i.e. wood extraction and hauling costs are lower in areas with lower slopes. This can be explained by the applicability of cheaper extraction methods as well as higher road densities in the flatter areas.

The most frequently used extraction method was cableyarding. Taking all four cable-yarding classes togethertower yarding and long-distance yarding, up-hill and downhill-this method was assigned to $52 \%$ of the Swiss forest area. This is not surprising given the large proportion of the forest area located in steep terrain. Similarly, Kuhmaier and Stampfer (2010) found that in steep terrain, cable-yarding was the dominant extraction method assigned by their model. Ca. $65 \%$ of the forest area in the study by Caliskan and Karahalil (2017) were assigned cable-crane extraction methods for a study area of partly steep terrain.

More surprising is the relatively high proportion of forest area labelled as "unsuitable terrain" and assigned air-based extraction (helicopter). This category resulted most often in the Southern Alps region (61\%) and quite often in the Alps (28\%), but also considerably often in the Pre-Alps (17\%) and Jura (11\%) regions. Even in the relatively flat Plateau area, $16 \%$ of the forest area was assigned air-based extraction. In some cases, this could be explained by the fact that even though a large road is present in a forest area, it might not be connected to the higher-order road network by suitable connection roads, e.g. due to obstacles like underpasses or bridges, so in our model the road is not used at all. This leads to the classification of a substantial area as "unsuitable terrain" where in reality wood is harvested using cable- or ground-based methods and transported in smaller trucks of less than $26 \mathrm{t}$ total weight. Then, even in the relatively flat terrain of the Plateau area steep forested slopes occur, 
Fig. 5 Production regions in Switzerland as defined in the Swiss NFI (Fischer and Traub 2019)

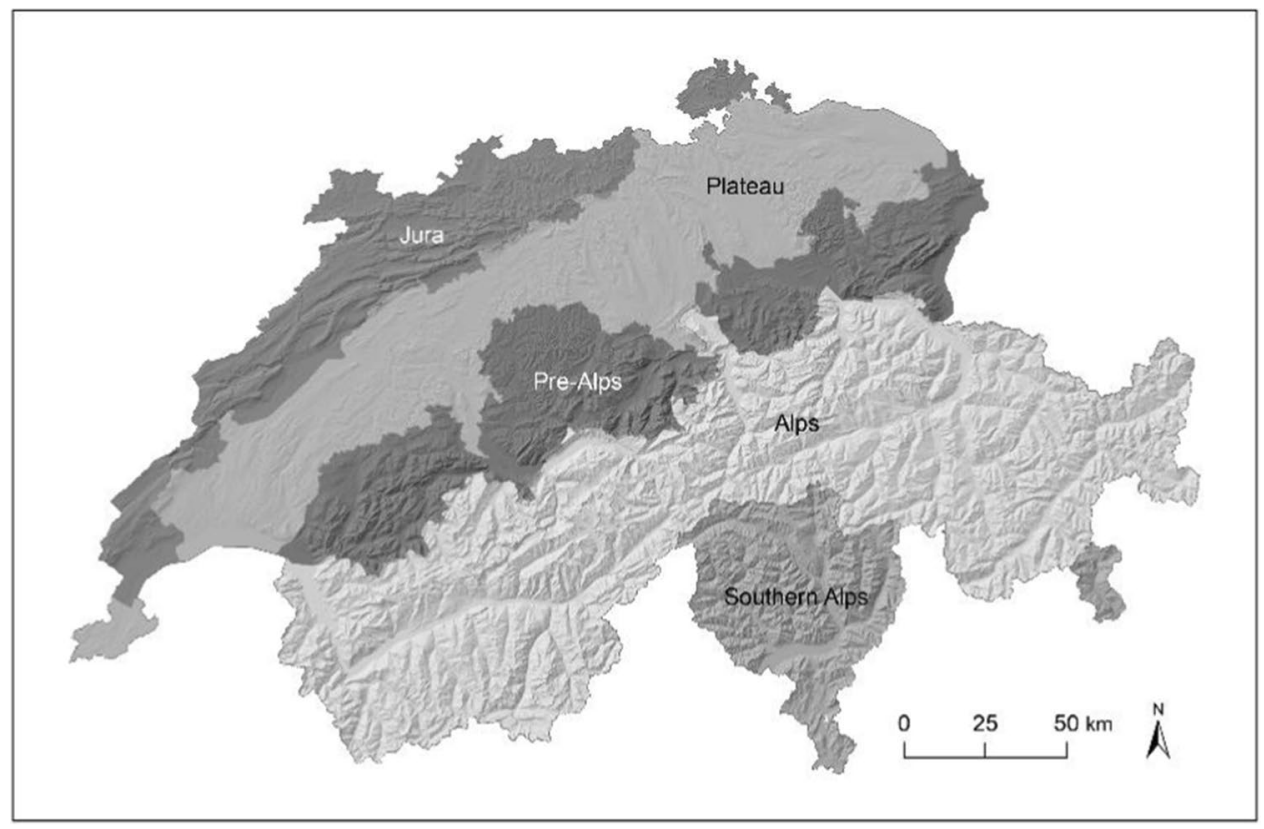

e.g. along creeks, as well as areas that are separated from the nearest road by obstacles such as power lines or railway lines. Third, also in areas with low relief and generally gentle slopes some forests are connected by small roads, only carrying vehicles of up to $25 \mathrm{t}$ total weight, which are not considered in our model. Finally, a missing connection point on the higher-order road network, or an existing road segment that was not recorded in the survey, would also lead to an area being classified as unsuitable terrain, even though a connection via large enough roads is present in reality.

Ground-based extraction was assigned to $21 \%$ of the forest area across Switzerland. It is almost negligible in the Southern Alps (3\% of the forest area), the Alps (4\%) and the Pre-Alps (9\%), according to our model, but accounts for a large proportion of the forest area in the Jura (40\%) and the Plateau (61\%). Accordingly, less than $10 \%$ of the growing stock would be extracted using ground-based methods in the Southern Alps, (2\%), Alps (3\%) and Pre-Alps (8\%). These values are comparable to a study by Zambelli et al. (2012) in a predominantly mountainous area (Trentino, Italy) where about $4-16 \%$ of estimated timber harvest volume could be extracted by ground-based methods. Ground-based extraction is assigned to stands with small distances to the nearest forest road, low slopes and good soil trafficabilities. Therefore, the reliability of this classification heavily depends on the input data for terrain and soil trafficability. While a digital terrain model of high resolution and accuracy was available as input for our model, information on soil characteristics was much more difficult to obtain. Better soil property maps would significantly improve the reliability of the assessment of trafficable forest areas in our model. In addition, the area where ground-based extraction is used may be underestimated by our model because it does not take into account the use of skid roads, which are often used instead of cable lines in steep terrain in reality. Roads missing in the road dataset will also reduce the forest area assigned to ground-based extraction.

Our results show that using the criteria given in Table 6, the Swiss forest road network is suitable for economic wood extraction in about $80 \%$ of the forest area in the Jura and Plateau regions; this percentage is considerably lower in the Alps and Southern Alps (30 and 16\%, respectively), while the Plateau region falls into the middle with $61 \%$. In the Plateau and Jura regions, forest areas deemed "not suitable" are often limited to small areas with steep topography and forest patches served only by smaller roads. In the regions with more mountainous topography, larger roads can sometimes only be found along the valley bottom, and correspondingly, large areas fall into the "not suitable" category.

We compared the resulting extraction methods to data from the $4^{\text {th }}$ Swiss NFI interview survey on the extraction method that was used or might be used on the NFI sample plots (1.41-km grid). In forests where harvesting actually took place in the time period since the previous survey, the dominant extraction method was "groundbased" $(80 \% \pm 1$ of the area), followed by "tower-yarding" $(15 \% \pm 1)$ and "helicopter" $(5 \% \pm 0)$ according to NFI data. The most probably applied extraction method for the forests that were not harvested in the same time period was "ground-based" $(41 \% \pm 1)$, followed by "tower-yarding" $(30 \% \pm 1)$ and "helicopter" $(29 \% \pm 1)$ (WSL 2020). This makes sense because a part of the area where expensive extraction methods would have to be applied are, in reality, not harvested at all. For the entire forest area, harvested 


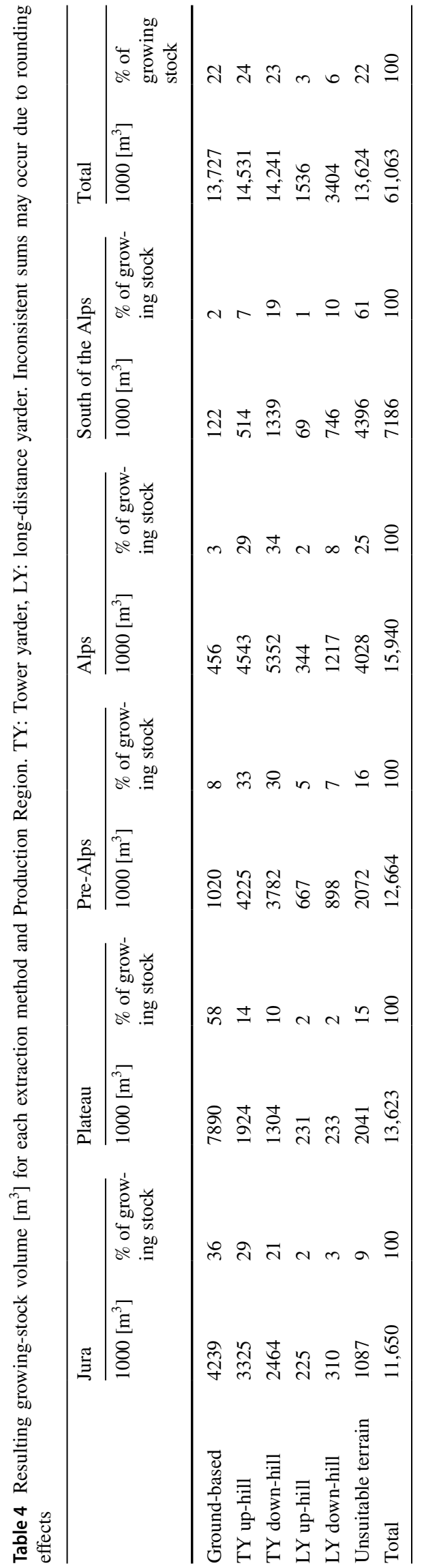

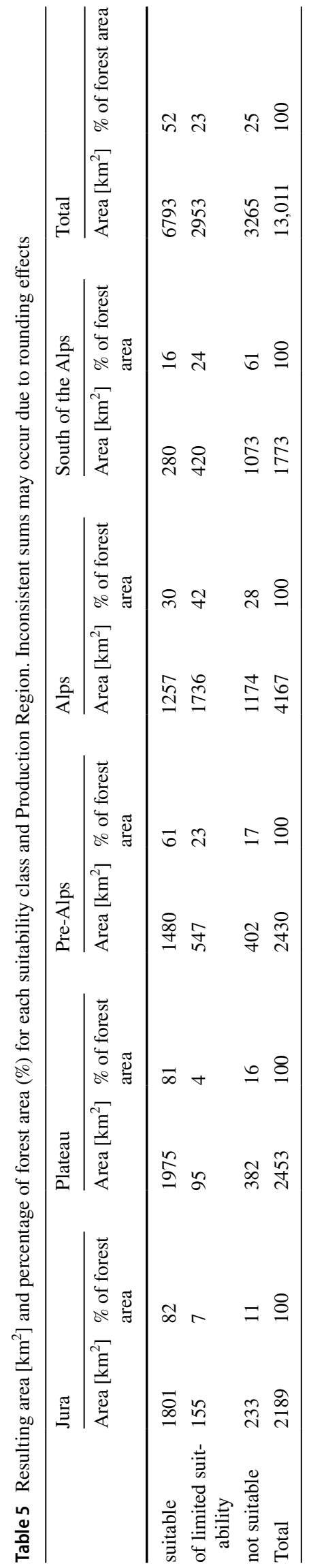


(a)

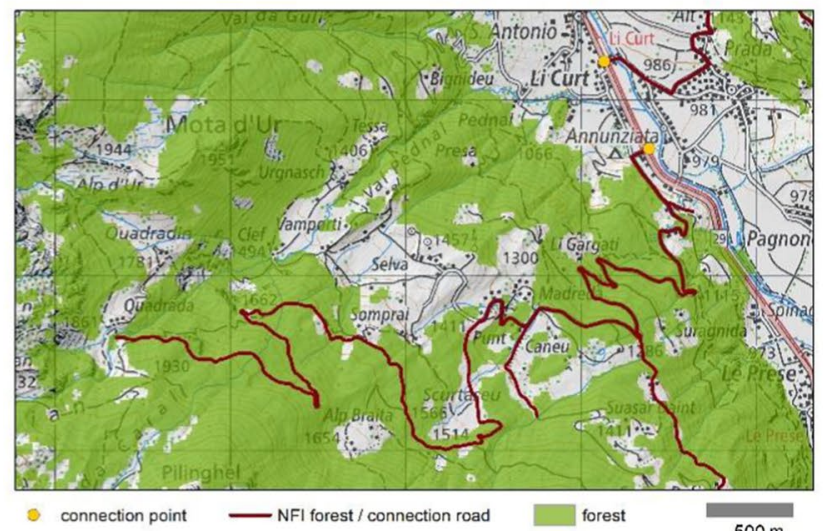

(c)

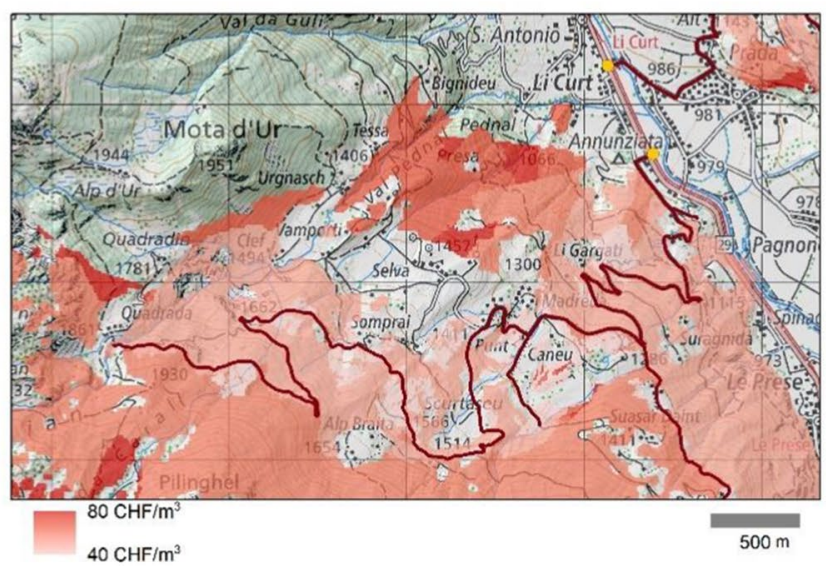

(e)

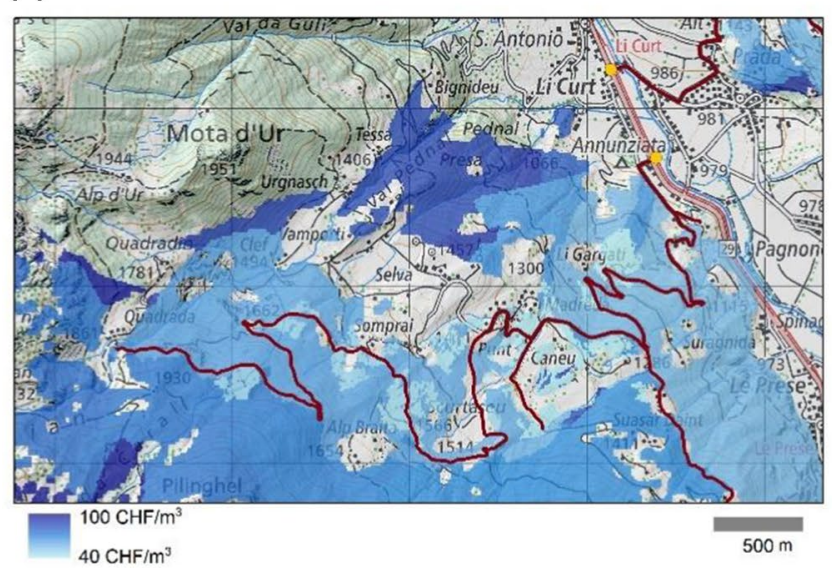

(b)

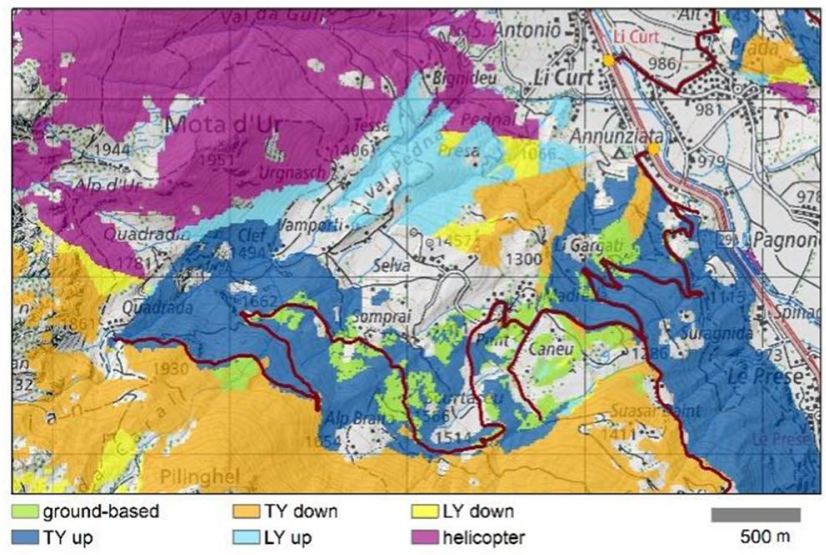

(d)

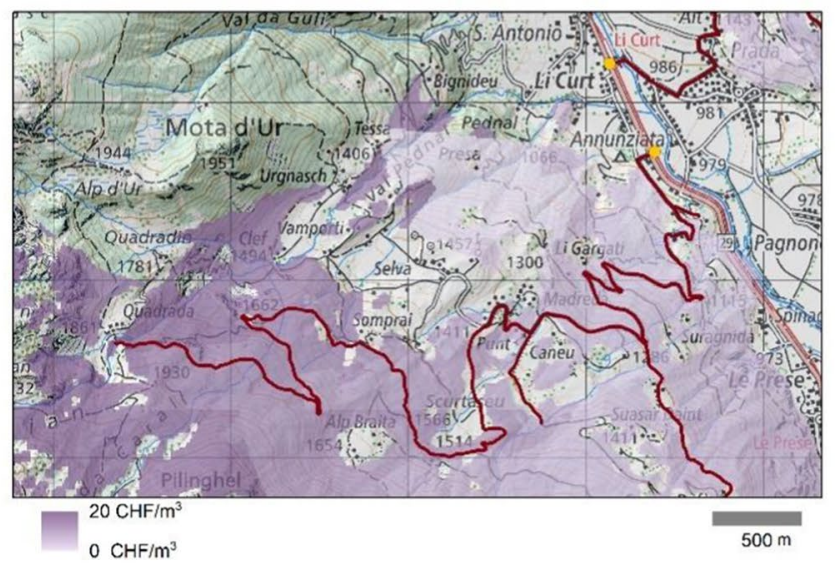

(f)

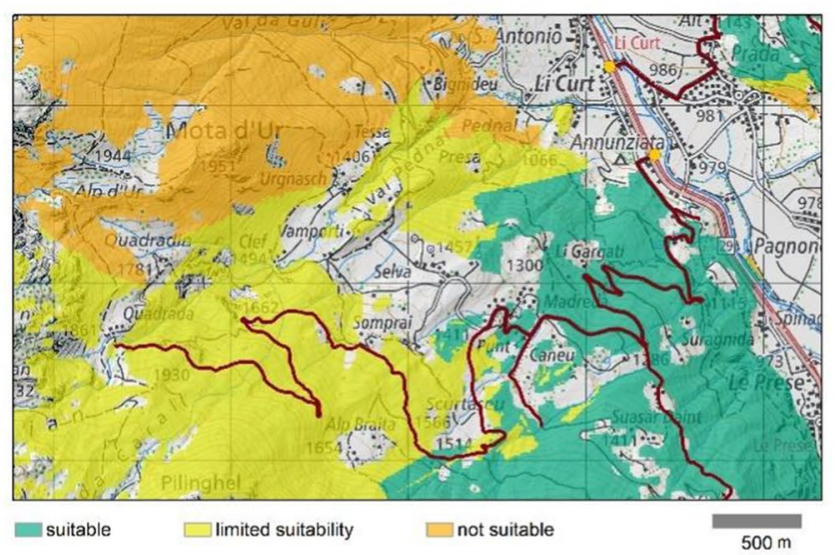

Fig. 6 a forest mask, $\mathbf{b}$ assigned extraction method, $\mathbf{c}$ extraction cost, $\mathbf{d}$ hauling cost, $\mathbf{e}$ total cost, $\mathbf{f}$ overall suitability according to the criteria in Table 6

or not, ground-based extraction was indicated for $53 \%$ of the area, tower-yarding for $25 \%$ and helicopter for $21 \%$ according to NFI data. The higher percentage of groundbased extraction can be explained by the fact that in the NFI survey, ground-based extraction includes winching.
In addition, the extraction method often depends on the machinery available in a forest enterprise.

We also presented our results - the extraction method map and the general suitability map-to the local forest services in two cantons, Basel and Bern, located in 
Table 6 Criteria for the 3 categories of suitability for economic wood extraction and hauling. TY: Tower yarder, LY: long-distance yarder

\begin{tabular}{lll}
\hline & $\begin{array}{l}\text { Forest road weight limitation (bearing } \\
\text { capacity) }\end{array}$ \\
\hline Extraction method & $\geq 20 \mathrm{t},<28 \mathrm{t}$ & $\geq 28 \mathrm{t}$ \\
ground-based & limited suitability & suitable \\
TY & limited suitability & suitable \\
LY & limited suitability & limited suitability \\
Helicopter & not suitable & not suitable \\
\hline
\end{tabular}

different parts of Switzerland, for feedback. The evaluated area covers the Jura, Plateau, Pre-Alps and Alps regions and represents the entire range of topographies in Switzerland. While our contact persons generally considered the results to be accurate, there were also some minor points of disagreement (S. Blatter, M. Opiasa, personal communication, 2019): first, the resulting areas allocated to a certain extraction method were sometimes very small, in some cases down to individual $10 \times 10 \mathrm{~m}$ pixels. This is owed to the combination of different input data with different spatial granularity and cannot completely be excluded, although applying different extraction methods for very small parcels does not make sense in practice. We stress that the resulting extraction-method map is suitable to give a general overview, not detailed instructions. Second, in practice, wood extraction systems were used in the cantons that were not considered in our model (winching in areas with a slope of more than $35 \%$ ). Still, we chose not to include any additional methods in the model to keep model complexity within limits. Third, forest services reported additional roads that were missing in our dataset, sometimes but not always because they had been constructed after the forest road survey. This highlights the importance of the completeness and up-to-dateness of the road input dataset. Fourth, cable-yarding was deemed unrealistic in some areas because no anchor trees were available or the distances were too short, or impossible because of very steep slopes (rock faces). We changed the model to exclude cable-yarding across very steep slopes. Fifth, in some cases soil trafficability was reported incorrect, for example, where waterlogging occurred. While a better soil property map for all of Switzerland was not available, this stresses the relevance of detailed information on soils for the assessment of wood extraction methods. When using the model for smaller areas with better soil information available, this should be included in the input data.

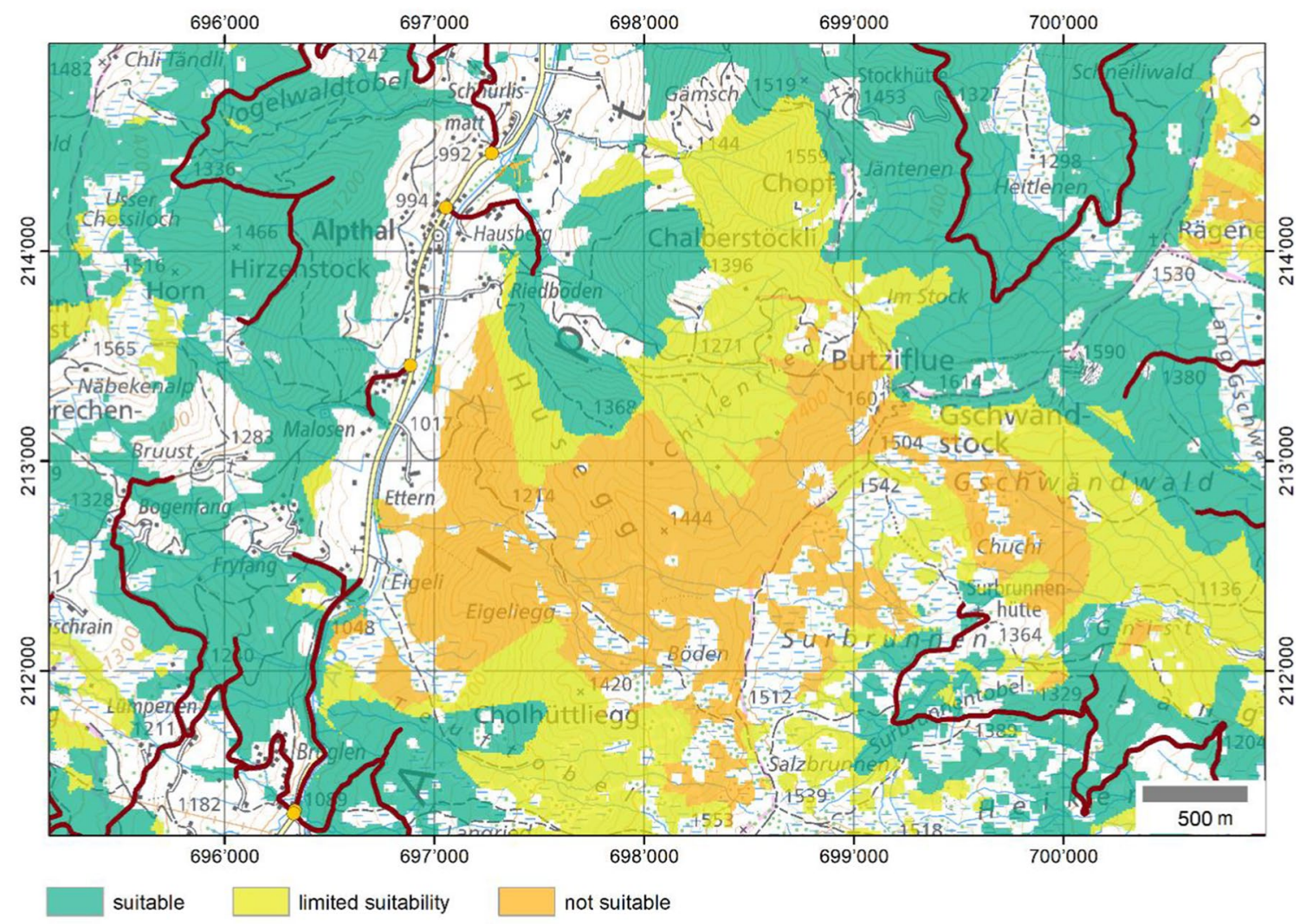

Fig. 7 Example of a forest area where a gap in the forest road network leads to a classification of the forest as "not suitable" for economic wood extraction and hauling 
The accuracy of the results depends strongly on the reliability of the road data, i.e. on how correct and how up-todate they are. It is thus very important to use a road dataset that provides the necessary information on bearing capacities. This information might have been documented during road construction, could be obtained from the owner of the road, requested from forestry services (as in the Swiss NFI) or collected in the field, but in any case should be consistent throughout the study area.

The effect of different raster resolutions was not analysed in this study, but would be important to investigate. We speculate that a higher resolution of the input data might improve results in some areas, but also introduce noise (i.e. too much detail) in other areas and in general lead to more small-scale effects in the results (i.e. very small areas with the same assigned extraction method). This effect might limit their practical value, but might be negligible in the case of a general evaluation of a large region. Dupire et al. (2015) demonstrated that in their study area the DTM resolution had an effect on the extraction distance for ground-based as well as cable-road extraction.

Our model uses a set of three different extraction methods (with different lengths for the cable-yarding), excluding other methods that may be applied in some regions. Another critical factor is the soil suitability map, which has limited resolution. Better representation of soil trafficability, thus describing vulnerability to compaction (e.g. areas prone to waterlogging, or skeletal fraction) and terrain roughness, might significantly improve the assignment of a suitable extraction method. The model could also be improved by better incorporating the analysis of obstacles to ground-based extraction.

Our model focuses on the economic efficiency of wood extraction and hauling. Depending on the problem to be solved, other factors such as ecological or safety considerations have to be taken into account. Extraction costs are difficult to estimate and vary with time; further investigation would be required to analyse the model's sensitivity to changing cost assumptions. While absolute cost estimations should be used with care, given the difficulty of assigning accurate costs to wood extraction procedures and hauling, our model is better suited to give a reasonable relative classification over a large area, for example, by using a suitability index such as the rating shown in Table 6.

From the point of view of planning improvements of the forest road network to increase economic efficiency, it would also be important to identify areas where road densities are higher than necessary.

\section{Conclusions}

In this paper, we have presented an approach that allows to assess the economic efficiency of the forest road network in the heterogeneous terrain of Switzerland. Our results show that the model developed by Bont et al. (2018) gives a reasonable assessment of the relative accessibility of wood in the forests of a fairly large region of variable terrain; however, a few changes were introduced to more realistically include areas with flat terrain or gentle slopes. The results of the assessment, together with more detailed information on forest composition, protection function and local soil conditions, for example, can be used to identify areas of insufficient efficiency. This is important because it allows limited means for road construction and improvement to be allocated in a more economically efficient way.

The main advantage of our model compared to assessment by expert opinion is that a large area can be assessed objectively, using the same criteria everywhere, thus providing comparable results. This comes at the cost of ignoring local detail. In contrast to many classical approaches, such as road density analysis, our model gives spatially explicit results. The main advantage of our model compared to other area-wide (spatially explicit) methods is that off- and on-road wood transport are considered simultaneously.

Our results show that the suitability of the Swiss forest road network for economic wood extraction varies strongly between regions, with the best results for the Jura and Plateau regions. The lowest percentage of forest area with a suitable forest road network is found in the Southern Alps.

Ground-based extraction only plays a significant role in the Jura and Plateau regions, whereas in the Pre-Alps and Alps regions, cable-yarding is assigned to a larger percentage of forest area. In the Southern Alps, the largest share of forest area falls into the category of "unsuitable terrain".

The results do not intend to be a precise recommendation about which extraction method should be used at a certain place, but an indication of which areas are not covered by a road network of sufficient density and bearing capacity for wood to be harvested economically at the moment. The power of the method lies in making the assessment of different areas comparable, whereas the absolute numbers of the cost estimates strongly depend on the cost assumptions in the model, for which reliable numbers are often difficult to obtain. Individual forest managers might arrive at different conclusions when considering available machinery and preferred vehicle types in their forest districts, as well as the wood volume to be harvested in a given harvesting operation. Note that protective forests are included in the analysed forest area but do not need to fulfil the same efficiency criteria as other forests, since wood harvesting will be conducted here even if it is not economic.

Apart from the assessment of the status quo of the forest road network in a given area, the model could be applied to specific case studies such as the evaluation of the wood potential for suggested locations for saw mills, or the analysis of the effects of road upgrades or removals. 
Acknowledgements We thank the forest services of the cantons of Basel and Bern for evaluating our results and providing valuable feedback on the model results. We would also like to thank two anonymous reviewers whose comments and suggestions helped improve the manuscript. The project was funded by the Swiss Federal Institute for Forest, Snow and Landscape Research (WSL) and the Swiss Federal Office for the Environment (BAFU).

Authors' contributions L.G. Bont developed the original code. M. Fraefel and L. Bont adapted the code. M. Fraefel performed the analysis and took the lead in writing the manuscript. C.Fischer helped with the interpretation. All authors contributed to the manuscript and read and approved of its final version.

Funding Open Access funding provided by Lib4RI - Library for the Research Institutes within the ETH Domain: Eawag, Empa, PSI. The project was funded by the Swiss Federal Institute for Forest, Snow and Landscape Research (WSL) and the Swiss Federal Office for the Environment (BAFU).

Data availability NFI data used and produced in this study may be available on request (https://www.lfi.ch/dienstleist/daten-en.php?lang= en). Third-party data (swissTLM ${ }^{3 \mathrm{D}}$, swiss ALTI $^{3 \mathrm{D}}$, Swiss soil suitability map) from swisstopo and the Swiss Federal Statistical Office were used under licence for this study.

\section{Declarations}

Conflicts of interest The authors declare that they have no conflict of interest.

Open Access This article is licensed under a Creative Commons Attribution 4.0 International License, which permits use, sharing, adaptation, distribution and reproduction in any medium or format, as long as you give appropriate credit to the original author(s) and the source, provide a link to the Creative Commons licence, and indicate if changes were made. The images or other third party material in this article are included in the article's Creative Commons licence, unless indicated otherwise in a credit line to the material. If material is not included in the article's Creative Commons licence and your intended use is not permitted by statutory regulation or exceeds the permitted use, you will need to obtain permission directly from the copyright holder. To view a copy of this licence, visit http://creativecommons.org/licenses/by/4.0/.

\section{References}

Abegg M et al. (2014) Viertes Schweizerisches Landesforstinventar - Ergebnistabellen und Karten im Internet zum LFI 2009-2013 (LFI4b). [Published online 06.11.2014] Available from World Wide Web <http://www.lfi.ch/resultate/>. Eidg. Forschungsanstalt WSL. Accessed 02 March 2020

Akay A, Kakol A Forest Transportation Planning by using GIS-based Decision Support System. In: 5th Forest Engineering Conference with 47th International Symposium on Forestry Mechanisation, Gerardmer, France, 2014.

Alberdi I et al (2020) Assessing forest availability for wood supply in Europe. Forest Policy Econ 111:102032. https://doi.org/10.1016/j. forpol.2019.102032

Bont L, Heinimann H, Church R (2015) Concurrent optimization of harvesting and road network layouts under steep terrain. Ann Oper Res 232:41-64. https://doi.org/10.1007/s10479-012-1273-4
Bont L, Heinimann HR (2012) Optimum geometric layout of a single cable road. Eur J Forest Res 131:1439-1448. https://doi.org/10. 1007/s10342-012-0612-y

Bont LG, Fraefel M, Fischer C (2018) A spatially explicit method to assess the economic suitability of a forest road network for timber harvest in steep terrain. Forests 9:169

Bont LG, Maurer S, Breschan JR (2019) Automated Cable Road Layout and Harvesting Planning for Multiple Objectives in Steep Terrain. Forests 10:687

Brändli U-B, Abegg M, Allgaier Leuch B (eds) (2020) Schweizerisches Landesforstinventar. Ergebnisse der vierten Erhebung 2009-2017. Eidgenössische Forschungsanstalt für Wald, Schnee und Landschaft WSL / Bundesamt für Umwelt, Birmensdorf / Bern

Brändli U-B, Fischer C, Camin P (2016) Stand der Walderschliessung mit Lastwagenstrassen in der Schweiz. Schweiz Z Forstwes 167:143-151. https://doi.org/10.3188/szf.2016.0143

Brassel P, Lischke H (eds) (2001) Swiss National Forest Inventory: methods and models of the second assessment. Swiss Federal Research Institute WSL, Birmensdorf

Bundesamt für Umwelt BAFU (ed) (2013) Waldpolitik 2020. Visionen, Ziele und Massnahmen für eine nachhaltige Bewirtschaftung des Schweizer Waldes. Bundesamt für Umwelt, Bern

Bundesamt für Umwelt BAFU (ed) (2017) Jahrbuch Wald und Holz 2017. vol 1718. Umwelt-Zustand, Bern

Caliskan E, Karahalil U (2017) Evaluation of forest road network and determining wood extraction system using GIS: A case study in anbardag planning unit. Sumarski List 141:163-171. https://doi. org/10.31298/sl.141.3-4.6

Croci-Maspoli M et al. (2018) CH2018 - Climate Scenarios for Switzerland-Technical Report.

Dupire S, Bourrier F, Monnet J-M, Berger F (2015) Sylvaccess: Un modèle pour cartographier automatiquement l'accessibilité des forêts. Revue Forestiere Francaise

Eichrodt AW, Heinimann HR Mobility of Timber Harvesting Vehicles. Proceedings "Appalachian Hardwoods: Managing Change". In: Council on Forest Engineering (COFE), Snowshoe, USA, 2001. pp 1-6

Erni V (2003) HeProMo-Produktivitätsmodelle für Holzerntearbeiten. Windows-Software. Eidgenössische Forschungsanstalt WSL, Birmensdorf

Fischer C, Camin P (2015) Holznutzung und Zuwachs. In: Rigling A, Schaffer HP (eds) Waldbericht 2015. Zustand und Nutzung des Schweizer Waldes. Bundesamt für Umwelt, Eidg. Forschungsanstalt für Wald, Schnee und Landschaft (WSL), Bern, Birmensdorf, pp 60-61

Fischer C, Fraefel M (2019) Interview survey with the local forest service. In: Fischer C, Traub B (eds) Swiss National Forest Inventory-Methods and models of the fourth assessment. Springer, Cham, pp 187-195. https://doi.org/10.1007/978-3-030-19293-8 10

Fischer C, Stadelmann G (2019) Calculation of potential timber harvesting costs (HeProMo). In: Fischer C, Traub B (eds) Swiss National Forest Inventory-Methods and models of the fourth assessment. Springer, Cham, pp 257-263

Fischer C, Traub B (eds) (2019) Swiss National Forest Inventory Methods and models of the fourth assessment vol 35. Managing forest ecosystems. Springer, Cham

Fraefel M, Fischer C (2019) Compilation of a high-quality forest road data set. In: Fischer C, Traub B (eds) Swiss National Forest Inventory-Methods and models of the fourth assessment. Springer, Cham, pp 367-373. https://doi.org/10.1007/978-3-030-19293-8_ 22

Frutig F, Thees O, Lemm R, Kostadinov F (2009) Holzernteproduktivitätsmodelle HeProMo-Konzeption, Realisierung, Nutzung und Weiterentwicklung. In: Thees O, Lemm R (eds) Management 
zukunftsfähige Waldnutzung. Grundlagen, Methoden und Instrumente. Vdf: Zürich, pp 441-466

Ghaffariyan MR, Stampfer K, Sessions J (2010) Optimal road spacing of cable yarding using a tower yarder in Southern Austria. Eur J Forest Res 129:409-416. https://doi.org/10.1007/ s10342-009-0346-7

Ginzler C et al (2019) Area-wide products. In: Fischer C, Traub B (eds) Swiss National Forest Inventory-Methods and models of the fourth assessment. Springer, Cham, pp 125-142. https://doi. org/10.1007/978-3-030-19293-8_7

Havimo M, Mönkönen P, Lopatin E, Dahlin B (2017) Optimising forest road planning to maximise the mobilisation of wood biomass resources in Northwest Russia. Biofuels 8:1-15. https://doi.org/ 10.1080/17597269.2017.1302664

Hayati E, Majnounian B, Abdi E (2012) Qualitative evaluation and optimization of forest road network to minimize total costs and environmental impacts. Iforest-Biogeosci for 5:121-125. https:// doi.org/10.3832/ifor0610-009

Heinimann HR (1986) Seilkraneinsatz in den Schweizer Alpen: Eine Untersuchung über die Geländeverhältnisse, die Erschliessung und den Einsatz verschiedener Seilanlagen. ETH Zürich

Henry HAL (2008) Climate change and soil freezing dynamics: historical trends and projected changes. Clim Change 87:421-434. https://doi.org/10.1007/s10584-007-9322-8

Hofer P et al. (2011) Holznutzungspotenziale im Schweizer Wald. Auswertung von Nutzungsszenarien und Waldwachstumsentwicklung. vol 1116. Umwelt-Wissen. Bundesamt für Umwelt (BAFU), Bern

Holm S, Frutig F, Lemm R, Thees O, Schweier J (2020) HeProMo: a decision support tool to estimate wood harvesting productivities. PLoS ONE 15:e0244289. https://doi.org/10.1371/journal.pone. 0244289

Kuhmaier M, Stampfer K (2010) Development of a multi-attribute spatial decision support system in selecting timber harvesting systems. Croat J for Eng 31:75-88

Laschi A, Neri F, Montorselli N, Marchi E (2016) A methodological approach exploiting modern techniques for forest road network planning. Croat J for Eng 37:319-331

Manzone M, Balsari P (2017) Comparison between helicopter and cable crane in logging operation. Chem Eng Trans 58:319-324. https://doi.org/10.3303/CET1758054

Müller K, Fraefel M, Cioldi F, Camin P, Fischer C (2016) Der Datensatz «Walderschliessungsstrassen 2013» des Schweizerischen Landesforstinventars. Schweiz Z Forstwes 167:136-142. https:// doi.org/10.3188/szf.2016.0136

Murbach F (2016) Economic valuation of standing timber stock in Switzerland / Ökonomische Bewertung des stehenden Holzvorrates der Schweiz vol 1129-1600. Swiss Federal Statistical Office, Neuchatel

Pestal E (1961) Seilbahnen und Seilkräne für Holz-und Materialtransporte. Georg Fromme \& Co., Vienna, Austria / Munich, Germany

Spellerberg IF (1998) Ecological effects of roads and traffic: a literature review. Global Ecol Biogeogr Lett 7:317-333. https://doi.org/10. 2307/2997681
Stadelmann G, Herold A, Didion M, Vidondo B, Gómez A, Thürig E (2016) Timber-harvesting potential of Swiss forests: simulation of management scenarios [Holzerntepotenzial im Schweizer Wald: Simulation von Bewirtschaftungsszenarien]. Schweiz Z Forstwes 167:152-161. https://doi.org/10.3188/szf.2016.0152

Stückelberger JA, Heinimann HR, Chung W, Ulber M Automatic roadnetwork planning for multiple objectives. In: Chung W, Han HS (eds) The 29th Council on Forest Engineering. Working Globally-Sharing Forest Engineering Challenges and Technologies Around the World, Coeur d'Alene, Idaho, 2006. pp 233-248

Suvinen A (2006) A GIS-based simulation model for terrain tractability. J Terramech 43:427-449. https://doi.org/10.1016/j.jterra. 2005.05.002

Swiss Federal Statistical Office (FSO) (2000) Swiss soil suitability map Swiss Federal Statistical Office FSO. https://www.bfs.admin. $\mathrm{ch} / \mathrm{bfs} / \mathrm{en} / \mathrm{home} / \mathrm{services/geostat/swiss-federal-statistics-geodata/}$ land-use-cover-suitability/derivative-complementary-data/swisssoil-suitability-map.html. Accessed 25.05. 2020

swisstopo (2012) swissTLM3D Version 1.1 Ausgabe 2012 - Nachführungsinformation. Bundesamt für Landestopografie, Bern

swisstopo (2018) swissALTI3D. Das hoch aufgelöste Terrainmodell der Schweiz. Bundesamt für Landestopografie, Bern

The MathWorks Inc. (2016) Matlab version 9.1.0.441655 (R2016b) edn., Natick, Massachusetts

Wald Schweiz Fichten- und Tannen-Durchschnittspreise 2015-2019 (aller Sortimente zusammengenommen) der von Agristat und WaldSchweiz in der gesamten Schweiz durchgeführten Rohholzpreiserhebungen. https://www.waldschweiz.ch/schwe izer-wald/holzmarkt/holzpreise/nadelstammholzleitsortimente/. Accessed October 2, 2019

Waser L, Fischer C, Wang Z, Ginzler C (2015) Wall-to-Wall Forest Mapping Based on Digital Surface Models from Image-Based Point Clouds and a NFI Forest Definition. Forests 6:4510-4528. https://doi.org/10.3390/f6124386

WSL (2020) Schweizerisches Landesforstinventar LFI. Spezialauswertung der Erhebung 2009-17 vom 2. Mai 2020. Christoph Fischer. Eidg. Forschungsanstalt WSL, Birmensdorf

Yonov N, Velichkov V (2004) Country report - Bulgaria. Hrubá Skála (Czech Republic)

Zambelli P, Lora C, Spinelli R, Tattoni C, Vitti A, Zatelli P, Ciolli M (2012) A GIS decision support system for regional forest management to assess biomass availability for renewable energy production. Environ Model Software 38:203-213. https://doi.org/10. 1016/j.envsoft.2012.05.016

Zweifel O (1960) Seilbahnberechnung bei beidseitig verankerten Tragseilen. Schweizerische Bauzeitung 78

Publisher's Note Springer Nature remains neutral with regard to jurisdictional claims in published maps and institutional affiliations. 